\title{
Increases in the mutation frequency at which fusidic acid-resistant Staphylococcus aureus arise with salicylate
}

\author{
CHRISTOPHER T. D. PRICE*† and JOHN E. GUSTAFSON*† \\ * Microbiology Group, School of Biomedical Sciences, Curtin University of Technology, Perth 6845, Western \\ Australia and †Department of Microbiology, Chicago College of Osteopathic Medicine, Midwestern University, \\ Downers Grove, IL 60515, USA
}

\begin{abstract}
Salicylate was shown to increase the frequency at which a fusidic acid-susceptible strain of Staphylococcus aureus underwent mutation to become fusidic acid-resistant. These fusidic acid-resistant mutants had alterations in spectinomycin and kanamycin resistance levels indicative of mutations in fus $A$, the gene that encodes elongation factor-G, the target of fusidic acid.
\end{abstract}

\section{Introduction}

Previous studies showed that growth of Staphylococcus aureus in the presence of salicylate increased phenotypic resistance to fusidic acid and fluoroquinolones $[1,2]$. Fluoroquinolone-resistant mutants of $S$. aureus were also shown to arise at a greater frequency in the presence of salicylate [2]. As an extension to these studies, the effect of salicylate on the frequency of mutation to fusidic acid resistance in a fusidic acidsusceptible $S$. aureus strain was determined.

\section{Materials and methods}

Strains and population analyses

The well characterised S. aureus strain, BB255, was used in this study [3]. Fusidic acid-resistance population analyses were performed as described previously [1] on Luria Broth Agar (LBA; Difco) plates containing fusidic acid, with and without the addition of $2 \mathrm{mM}$ salicylate, ibuprofen, benzoate, acetaminophen, saligenin or acetate. Suspected fusidic acid-resistant colonies were subcultured from these plates and grown three times in drug-free Luria Broth (LB) overnight at $37^{\circ} \mathrm{C}$ and then stored in $\mathrm{LB}$ with glycerol $20 \% \mathrm{v} / \mathrm{v}$ at $-20^{\circ} \mathrm{C}$.

\section{MIC determinations}

Fusidic acid MIC determinations were performed by the agar dilution technique on Mueller-Hinton Agar

Received 1 March 2000; revised version received 26 April 2000; accepted 5 May 2000.

Corresponding author: Dr J. E. Gustafson.
(Oxoid) according to NCCLS guidelines. The gradientplate technique was used to determine kanamycin $(0-$ $4 \mathrm{mg} / \mathrm{L}$ gradient) and spectinomycin $(0-150 \mathrm{mg} / \mathrm{L}$ gradient) resistance levels as described previously [4].

\section{Chemicals}

Stock solutions of sodium salicylate $(1 \mathrm{M})$, sodium acetate $(1 \mathrm{M})$, sodium benzoate $(0.5 \mathrm{M})$ (BDH Laboratory Supplies, Poole) and sodium ibuprofen $(0.5 \mathrm{M})$ (Sigma) were made up in water. Acetaminophen $(0.5 \mathrm{M})$, acetylsalicylic acid $(0.5 \mathrm{M})$ (ICN Pharmaceuticals, Costa Mesa, CA, USA) and saligenin ( $0.5 \mathrm{M})$ (Sigma) stocks were made up in ethanol. The $\mathrm{pH}$ of these solutions was adjusted to 7 and, when required, they were filter-sterilised. All stock solutions were stored in dark containers at $4^{\circ} \mathrm{C}$. Sodium fusidate (Leo Pharmaceuticals, Ballerup, Denmark), kanamycin and spectinomycin (Sigma) were dissolved in water, filtersterilised and stored at $-20^{\circ} \mathrm{C}$.

\section{Results and discussion}

The addition of salicylate, ibuprofen or benzoate to media used in fusidic acid-resistance population analyses increased the number of cells surviving at otherwise inhibitory concentrations of fusidic acid (Fig. 1). The effect of ibuprofen on cell survival in the presence of fusidic acid was similar to that of salicylate, whereas the enhancement of cell survival by benzoate was less than with these compounds (Fig. 1). Acetaminophen, saligenin (the alcohol of salicylate) and acetate had no effect on fusidic acid-resistance population analyses in this study (data not shown). 


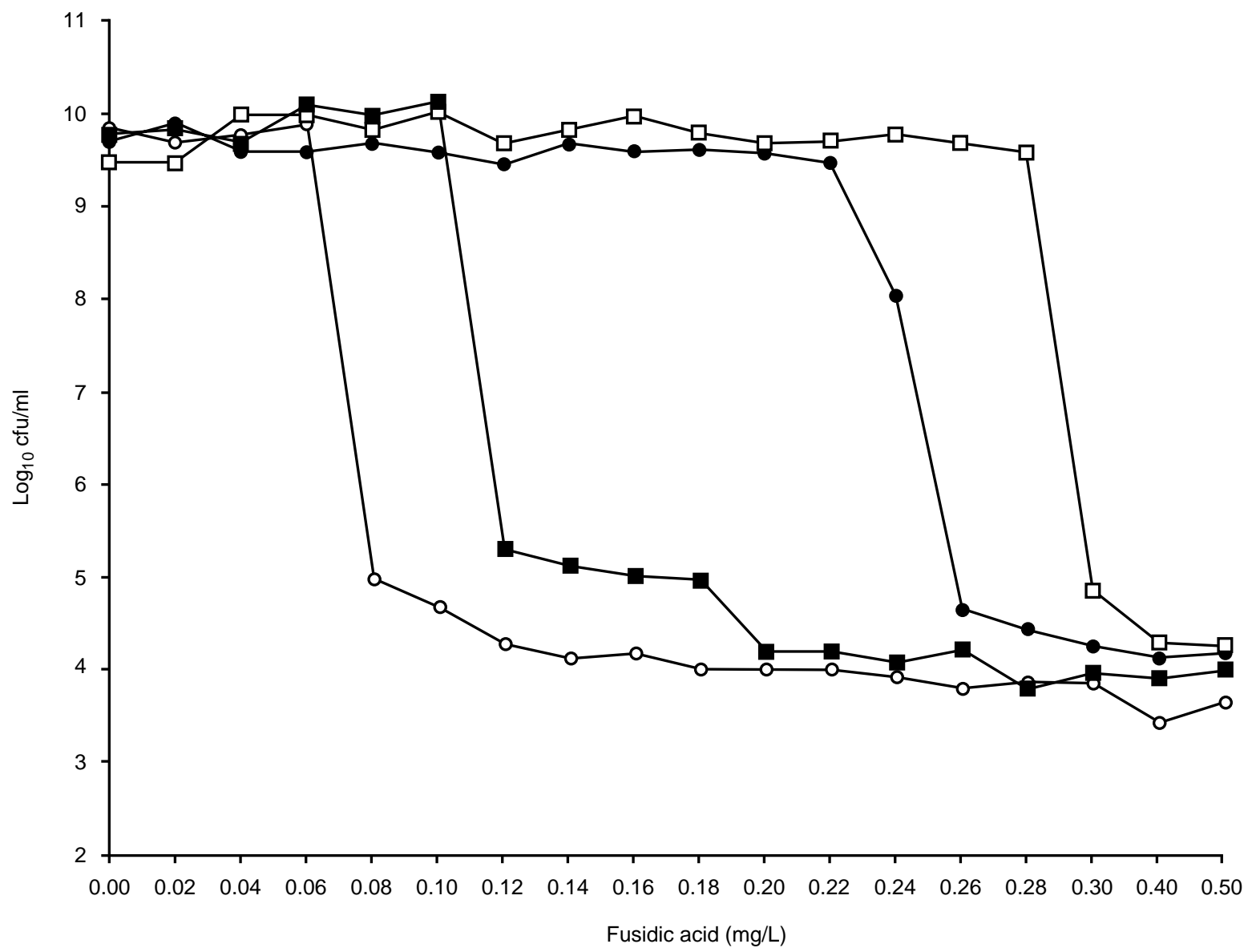

Fig. 1. Population analysis of strain BB255 in the presence of fusidic acid alone (O) or with $2 \mathrm{mM}$ salicylate (•), ibuprofen $(\square)$ or benzoate $(\mathbf{\square})$.

These data correlate with previous studies that demonstrated that compounds with an aromatic ring and a carboxylic acid functional group induce intrinsic fusidic acid resistance in S. aureus [1].

Individual colonies of strain BB255 surviving on plates containing fusidic acid 0.24 and $0.26 \mathrm{mg} / \mathrm{L}$, with and without $2 \mathrm{mM}$ salicylate, were isolated as described above and their fusidic acid MICs were determined (Table 1). Colonies surviving on fusidic acid $0.24 \mathrm{mg} / \mathrm{L}$ and $2 \mathrm{mM}$ salicylate had not become fusidic acid resistant by mutation (Table 1). It has been shown previously that salicylate can induce a phenotypic multiple antibiotic resistance mechanism in $S$. aureus $[1,2]$. All colonies selected from plates containing only fusidic acid $(0.24$ and $0.26 \mathrm{mg} / \mathrm{L})$ and fusidic acid $0.26 \mathrm{mg} / \mathrm{L}$ and $2 \mathrm{mM}$ salicylate had undergone mutation to become fusidic acid-resistant (Table 1). In the presence of salicylate and fusidic acid $0.26 \mathrm{mg} / \mathrm{L}$, the mutation frequency to become fusidic acid-resistant was 10 -fold greater than with fusidic acid $0.26 \mathrm{mg} / \mathrm{L}$ alone (Table 2). This demonstrates that salicylate can increase the mutation frequency of a susceptible strain of $S$. aureus to become resistant to fusidic acid.

Fusidic acid inhibits the translocation step of protein synthesis by interfering with the action of elongation factor-G (EF-G) [5]. Kanamycin and spectinomycin also interfere with the translocation step of protein synthesis [6-8]. Mutations leading to fusidic acid resistance in bacteria occur in fus $\mathrm{A}$, the gene encoding the target of fusidic acid, EF-G [4, 9, 10]. fus A mutations leading to fusidic acid resistance also alter resistance to kanamycin and spectinomycin in bacteria $[4,10]$. Kanamycin and spectinomycin gradient-plate MICs were determined for fusidic acid-resistant BB255 isolates from plates containing fusidic acid $0.26 \mathrm{mg} / \mathrm{L}$ with and without $2 \mathrm{mM}$ salicylate. Compared with strain BB255, all these isolates had increased kanamycin and reduced spectinomycin gradient-plate MICs, with the exception of isolate CP70, which demonstrated increased spectinomycin resistance (Table 3). Therefore, it is probable that these isolates all have mutations in fus $\mathrm{A}$, which leads to increased fusidic acid resistance.

This report and a previous study [2] demonstrate that the addition of salicylate can increase the mutation frequency of $S$. aureus at unrelated chromosomal loci in vitro, dependent on the antibiotic selection. How salicylate induces an increased mutation frequency to fusidic acid or fluoroquinolone resistance in $S$. aureus is unclear at present. Incorporation of salicylate into the Ames test under four different metabolic conditions failed to increase the revertant colony counts, indicating that salicylate has no mutagenic potential [11]. 
Table 1. Fusidic acid MICs of BB255 isolates from fusidic acid-resistance population analysis plates

\begin{tabular}{|c|c|c|c|c|c|}
\hline \multicolumn{3}{|c|}{ No salicylate } & \multicolumn{3}{|c|}{$2 \mathrm{mM}$ salicylate } \\
\hline Isolate no. & $\begin{array}{c}\text { Fusidic acid } \\
\text { concentration } \\
(\mathrm{mg} / \mathrm{L})\end{array}$ & $\begin{array}{c}\mathrm{MIC} \\
(\mathrm{mg} / \mathrm{L})\end{array}$ & Isolate no. & $\begin{array}{c}\text { Fusidic acid } \\
\text { concentration } \\
(\mathrm{mg} / \mathrm{L})\end{array}$ & $\begin{array}{c}\mathrm{MIC} \\
(\mathrm{mg} / \mathrm{L})\end{array}$ \\
\hline BB255 & 0 & 0.25 & CP73 & 0.24 & 0.25 \\
\hline CP63 & 0.24 & 16 & CP74 & 0.24 & 0.25 \\
\hline CP64 & 0.24 & 16 & CP75 & 0.24 & 0.25 \\
\hline CP65 & 0.24 & 16 & CP76 & 0.24 & 0.25 \\
\hline CP66 & 0.24 & 16 & CP77 & 0.24 & 0.25 \\
\hline CP67 & 0.24 & 8 & CP78 & 0.26 & 4 \\
\hline CP68 & 0.24 & 8 & CP79 & 0.26 & 4 \\
\hline СР69 & 0.26 & 16 & СР80 & 0.26 & 4 \\
\hline CP70 & 0.26 & 16 & CP81 & 0.26 & 8 \\
\hline CP71 & 0.26 & 16 & CP82 & 0.26 & 8 \\
\hline CP72 & 0.26 & 8 & CP83 & 0.26 & 4 \\
\hline
\end{tabular}

Table 2. BB255 fusidic acid resistance mutation frequencies

\begin{tabular}{lcc}
\hline $\begin{array}{l}\text { Fusidic acid } \\
\text { concentration } \\
\text { in plate }(\mathrm{mg} / \mathrm{L})\end{array}$ & $\begin{array}{c}\text { Addition of } \\
2 \mathrm{mM} \text { salicylate }\end{array}$ & $\begin{array}{c}\text { Mutation frequency } \\
\text { to } \mathrm{Fa}^{\mathrm{R}}\end{array}$ \\
\hline 0.24 & - & $1.29 \times 10^{-6}$ \\
0.24 & + & - \\
0.26 & - & $1.00 \times 10^{-6}$ \\
0.26 & + & $1.00 \times 10^{-5}$ \\
\hline
\end{tabular}

Table 3. Kanamycin and spectinomycin gradient plate MICs

\begin{tabular}{lcc}
\hline Isolate no. & $\begin{array}{c}\text { Kanamycin } \\
\text { MIC }(\mathrm{mg} / \mathrm{L})\end{array}$ & $\begin{array}{c}\text { Spectinomycin } \\
\text { MIC }(\mathrm{mg} / \mathrm{L})\end{array}$ \\
\hline BB255 & 1.2 & 77.5 \\
CP69 & $>4$ & 15 \\
CP70 & $>4$ & 106.25 \\
CP71 & $>4$ & 25 \\
CP72 & $>4$ & 26.25 \\
CP78 & $>4$ & 70 \\
CP79 & 1.73 & 57.5 \\
CP80 & 2.47 & 63.75 \\
CP81 & $>4$ & 67.5 \\
CP82 & $>4$ & 48.75 \\
CP83 & $>4$ & 61.25 \\
\hline
\end{tabular}

${ }^{*} \mathrm{CP} 69-\mathrm{CP} 72$ isolated from fusidic acid $0.26 \mathrm{mg} / \mathrm{L}$.

${ }^{\dagger} \mathrm{CP} 78-\mathrm{CP} 83$ isolated from fusidic acid $0.26 \mathrm{mg} / \mathrm{L}$ and $2 \mathrm{~mm}$ salicylate.

As growth in the presence of salicylate has a number of different effects on bacterial phenotypes [1, 2, 12-17], it is probable that salicylate-altered gene expression plays a role in altering mutation frequencies to antibiotic resistance during antibiotic resistance selection. Thus, research to determine the effects of salicylate and related compounds on the efficacy of antistaphylococcal therapies in vivo is warranted.

This work was funded by the Leo Research Foundation and the Australian Research Council. C. T. D. P. is a recipient of an Australian Postgraduate Scholarship.

\section{References}

1. Price CTD, O'Brien FG, Shelton BP, Warmington JR, Grubb WB, Gustafson JE. Effects of salicylate and related compounds on fusidic acid MICs in Staphylococcus aureus. J Antimicrob Chemother 1999; 44: 57-64.

2. Gustafson JE, Candelaria PV, Fisher SA et al. Growth in the presence of salicylate increases fluoroquinolone resistance in Staphylococcus aureus. Antimicrob Agents Chemother 1999; 43: $990-992$.

3. Berger-Bächi B, Kohler ML. A novel site on the chromosome of Staphylococcus aureus influencing the level of methicillin resistance: genetic mapping. FEMS Microbiol Lett 1983; 20: 305-309.

4. O’Brien FG, Botterill CI, Endersby TG, Lim RLG, Grubb WB, Gustafson JE. Heterogeneous expression of fusidic acid resistance in Staphylococcus aureus with plasmid or chromosomally encoded fusidic acid resistance genes. Pathology 1998; 30: $299-303$.

5. Tanaka N, Kinoshita T, Masukawa H. Mechanism of protein synthesis inhibition by fusidic acid and related antibiotics. Biochem Biophys Res Commun 1968; 30: 278-283.

6. Misumi N, Nishimura T, Komai T, Tanaka N. Interaction of kanamycin and related antibiotics with the large subunit of ribosomes and the inhibition of translocation. Biochem Biophys Res Commun 1978; 84: 358-365.

7. Cabañas MJ, Vázquez D, Modolell J. Inhibition of ribosomal translation by aminoglycoside antibiotics. Biochem Biophys Res Commun 1978; 83: 991-997.

8. Bilgin N, Richter AA, Ehrenberg M, Dahlberg AE, Kurland CG. Ribosomal RNA and protein mutants resistant to spectinomycin. EMBO J 1990; 9: 735-739.

9. Chopra I. Mechanisms of resistance to fusidic acid in Staphylococcus aureus. J Gen Microbiol 1976; 96: 229-238.

10. Johanson U, Hughes D. Fusidic acid-resistant mutants define three regions in elongation factor $\mathrm{G}$ of Salmonella typhimurium. Gene 1994; 143: 55-59.

11. Oldham JW, Preston RF, Paulson JD. Mutagenicity testing of selected analgesics in Ames Salmonella strains. J Appl Toxicol 1986; 6: 237-243.

12. Cohen SP, Levy SB, Foulds J, Rosner JL. Salicylate induction of antibiotic resistance in Escherichia coli: activation of the mar operon and a mar-independent pathway. J Bacteriol 1993; 175: $7856-7862$.

13. Domenico P, Schwartz S, Cunha BA. Reduction of capsular polysaccharide production in Klebsiella pneumoniae by sodium salicylate. Infect Immun 1989; 57: 3778-3782.

14 Kunin CM, Hua TH, Bakaletz LO. Effect of salicylate on expression of flagella by Escherichia coli and Proteus, Providencia, and Pseudomonas spp. Infect Immun 1995; 63: 1796-1799.

15. Kunin CM, Hua TH, Guerrant RL, Bakaletz LO. Effect of salicylate, bismuth, osmolytes, and tetracycline resistance on expression of fimbriae by Escherichia coli. Infect Immun 1994; 62: $2178-2186$.

16. Muller E, Al-Attar J, Wolff AG, Farber BF. Mechanism of salicylate-mediated inhibition of biofilm in Staphylococcus epidermidis. J Infect Dis 1998; 177: 501-503.

17. Sawai T, Hirano S, Yamaguchi A. Repression of porin synthesis by salicylate in Escherichia coli, Klebsiella pneumoniae and Serratia marcescens. FEMS Microbiol Lett 1987; 40: $233-237$. 